\title{
To Evaluate the Effect of Water Temperature and Duration of Immersion on the Marginal Accuracy and Microhardness of Provisional Restoration: An In Vitro Study
}

\author{
Sanjan Verma ${ }^{1}$ Tarun Kalra ${ }^{1} \quad$ Manjit Kumar $^{1} \quad$ Ajay Bansal $^{1} \quad$ Ritu Batra $^{2} \quad$ Abhishek Avasthi
}

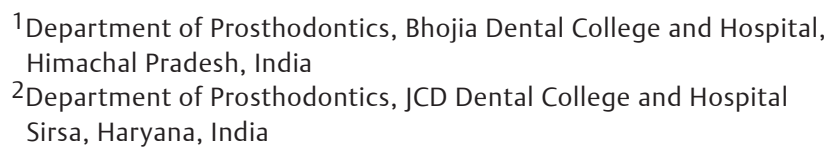

Address for correspondence Manjit Kumar, MDS, Department of Prosthodontics, Bhojia Dental College and Hospital, Himachal Pradesh 173250, India (e-mail: manjitkiran@yahoo.co.in).

Dent J Adv Stud:2020;8:115-126

\begin{abstract}
Introduction Provisional restoration is a critical component of fixed prosthodontics treatment, which must satisfy many inter-relative factors such as biological, mechanical, and esthetic. These restorations should have accurate marginal adaptation and optimum strength to maintain functional demands. The present "in vitro" study was conducted to evaluate the effect of water temperature and duration of immersion, on the marginal adaptation and microhardness of four different commercially available provisional restorative materials.

Materials and Methods The 240 specimens were then seated on the stainless-steel die which simulated the prepared tooth, and evaluated for the marginal gap for four different provisional restorative materials and divided into four different groups $A, B$, $C$, and D. Each group was further divided into six subgroups according to temperature of water and time of immersion. In each group the samples were immersed in water at 20,30 , and 40 degrees, respectively for 5 and 10 -minutes duration. Four different temporary restorative materials for crown fabrication were loaded each time to make temporary crowns.

Results Each sample was placed under travelling stereoscopic microscope (20x magnification) and photographed. Results for each surface were obtained, and the average of three surfaces was calculated. Knoop hardness was measured using a microhardness tester. The study was subjected to statistical analysis, to know the statistical significance, of the effect of difference in time and temperature changes at the time of final polymerization on surface microhardness and marginal integrity of four different provisional restorative materials.

Discussion The mean marginal discrepancies of bis-GMA (group B) at 20, 30, and $40^{\circ} \mathrm{C}$ for 5 and 10 minutes in water were smaller than the results of other groups. Microhardness evaluation showed that the poly ethyl methacrylate (PEMA) type resin exhibited significantly lower microhardness than the bis-acryl resin composites (Protemp 4 and Systemp.c\&b) at both time and temperature intervals.

Keywords

- microhardness

- provisional crowns

- ANOVA test

Conclusion The bis-acryl composites material has the least marginal discrepancy in comparison with PEMA and polymethyl methacrylate (PMMA). The bis-acryl composites materials exhibit superior surface microhardness followed by PEMA and PMMA.
\end{abstract}

DOI https://doi.org/

$10.1055 / \mathrm{s}-0040-1716315$

ISSN 2321-1482.
(C2020 Bhojia Dental College and Hospital affiliated to Himachal

Pradesh University
License terms

()(1) $\odot \circledast$ 


\section{Introduction}

The treatment modality in fixed prosthodontics is replacement and restoration of teeth by artificial substitute that are fixed in mouth ${ }^{1}$ This procedure involves preparation of the abutment teeth with removal of the protective layer of enamel exposing the sensitive dentine underneath. Following the preparation, the most important thing is that, the prepared tooth should be protected and it should be comfortable for the patient while the restoration is fabricated in the laboratory to accomplish this; immediate provisional restoration is given on prepared tooth. With this, patient's confidence is achieved which influences the long-term prognosis of definite prosthesis. Interim restorations must be provided to patients during extended treatment periods. ${ }^{2}$

Temporization is part and parcel of fixed prosthodontics, which must satisfy many inter-relative factors such as biological, mechanical, and esthetic. ${ }^{3}$ Provisional restoration helps in maintaining gingival health and vitality of tooth. They also help in preventing migration of abutment teeth, maintain aesthetic, helps in maintaining vertical dimension, and aid in developing anterior guidance and occlusal scheme. ${ }^{4}$

In anterior region provisional restorations give the clinician as well as the patient an idea about the color, contour, length, width, and shape of the teeth before fabrication of the final porcelain metal or all-porcelain restoration. ${ }^{5}$

The physical and mechanical properties of the material used for fabricating provisional restoration such as microhardness, flexural strength, resistance to wear, dimensionally stable, marginal adaptability, and resistance to staining and discoloration should be ideal. The marginal adaptation should be accurate and have optimum strength to maintain functional demands.

If a crown is luted for a short time, there are release of stresses and polymerization shrinkage. ${ }^{6}$ Marginal gap is measured as the perpendicular distance from the axial wall of preparation to the marginal surface of restoration. Due to poor marginal fit the fluids and bacteria may pass, that can make the tooth more prone to caries or pulpal infections. This can cause irritation to the soft tissue and lead to plaque deposition and periodontal diseases ranging from gingival recession, gingival inflammation with bleeding, especially in cases when the subgingival margins are prapared. $^{7}$

Cutting of specimens and embedding them, direct visual examination, through stereo- or electron-microscopy are the various methods to check the marginal adaptation. ${ }^{8}$

Hardness of a material can be used for its density, and a denser material is more resistant to wear and surface deterioration. ${ }^{9}$ Evaluation of microhardness tells us the material's capacity to maintain the diagnostic elements, i.e., the vertical dimensions of occlusion, and up to cementation of definitive prosthesis. $^{10}$
Thus, need arises to evaluate and investigate the marginal fit and microhardness of the different available provisional restorative materials. The present "in vitro" study was conducted to evaluate the effect of water temperature and duration of immersion, on the marginal adaptation and microhardness of four available materials used for fabrication of provisional restorations.

\section{Materials and Methods}

Two dies of stainless steel material were fabricated. The first die simulated the reverse architecture, i.e., negative replica of an unprepared tooth (female component), with dimensions of 12-mm base and axial wall height of $8.5 \mathrm{~mm}$ (-Fig. 1).

The second die simulating the prepared tooth (male component) with a base of 12-mm diameter. In the central base of die a prepared tooth was extended axially having axial height of $7 \mathrm{~mm}, 1-\mathrm{mm}$ shoulder margin with overall axial reduction of 1.5-mm clearance (-Figs. 2 and 3 ).

The two dies were made to seat accurately over each other by means of trichannel interlock system so that the same position is achieved every time on repeated removal and seating. Thus, spaces of $1 \mathrm{~mm}$ at the margin and $1.5 \mathrm{~mm}$ in the axial area are created for the provisional restorative material to form the crowns.

For this study water bath with equistat (MAC) having cut off temperature up to $99.9^{\circ} \mathrm{C}$ was used. The time and duration of immersion of ten samples each for provisional

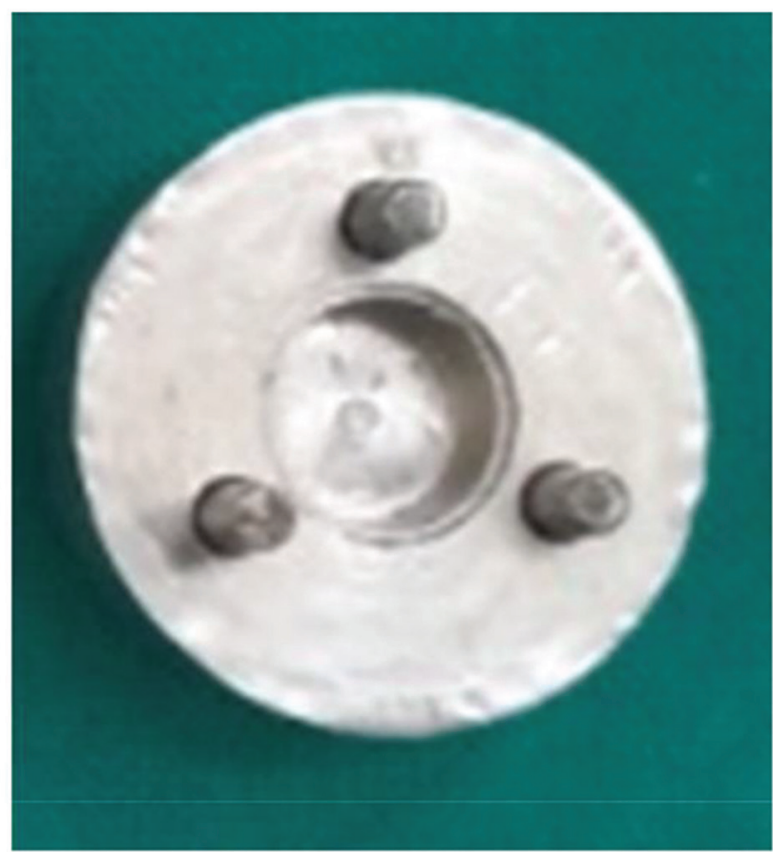

Fig. 1 Stainless steel die (negative replica of unprepared tooth). 


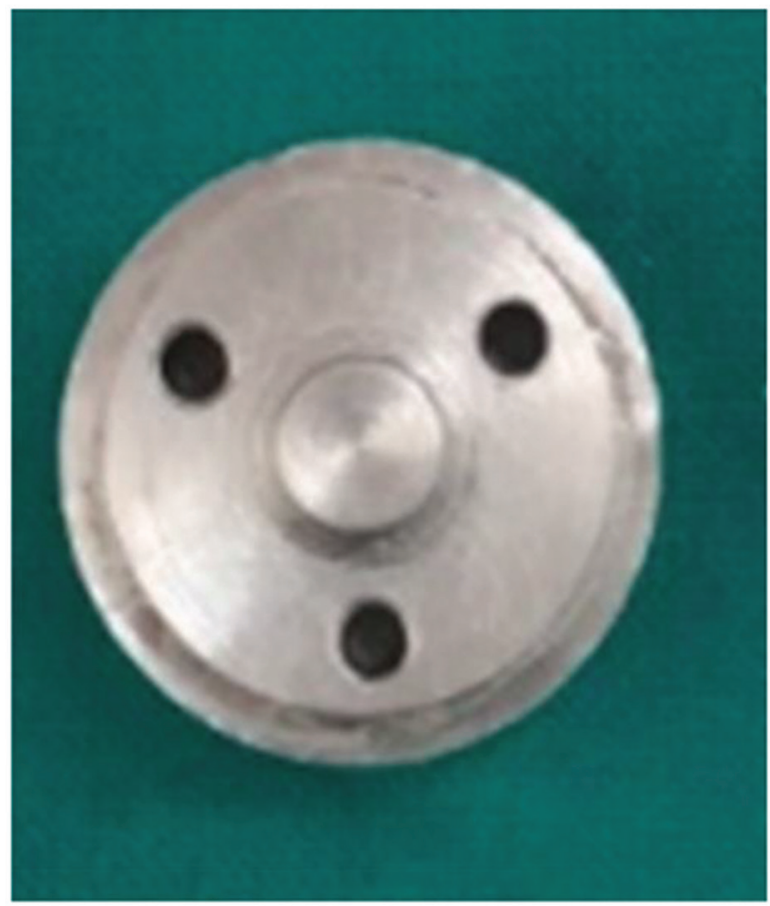

Fig. 2 Stainless steel die (prepared tooth).

restorative crowns were 5 and 10 minutes at 20,30, and 40 degrees, respectively.

Zeiss stereomicroscope was used and photograph was taken each time with Nikon camera (Nikon Corp). An image analyzing software (Image J) was then used to measure the distance, by drawing a parallel line from the crown margins and prepared tooth margin on the die. A millimeter ruler was placed in the field of view and photographed to computer program calibrations. Results for each surface were obtained at three points and an average value for each sample was calculated ( - Fig. 4 ).

Knoop hardness was measured after specimen fabrication with a microhardness tester (Chennai Metco) of 10-g load indenter ( - Fig. 5).

\section{Methodology}

\section{Preparation of Samples}

Total 240 provisional crowns were fabricated from four different provisional restorative materials and divided into four different groups A, B, C, and D. Each group was further divided into six subgroups according to temperature of water and time of immersion. In each group the samples were immersed in water at 20,30, and 40 degrees, respectively for 5 and 10 -minutes duration. Four different temporary restorative materials for crown fabrication were loaded each time to make temporary crowns having 1 -mm shoulder margin and over all width of $1.5 \mathrm{~mm}$.

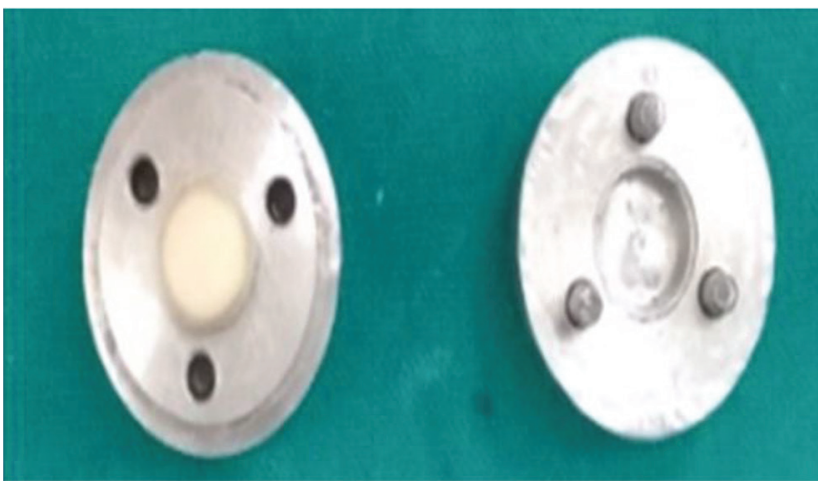

Fig. 3 Sample on master die.

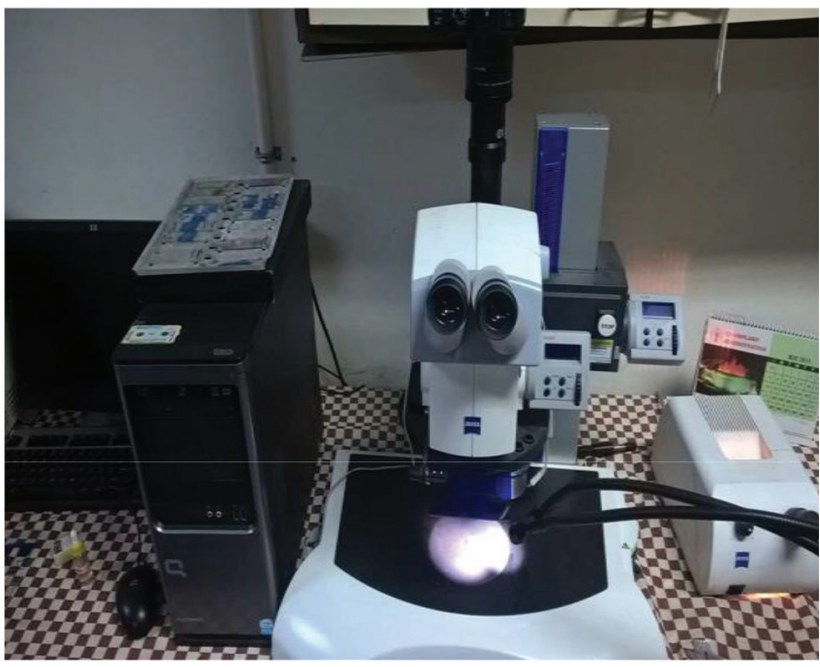

Fig. 4 Travelling Stereoscopic Microscope 20× (ZEISS).

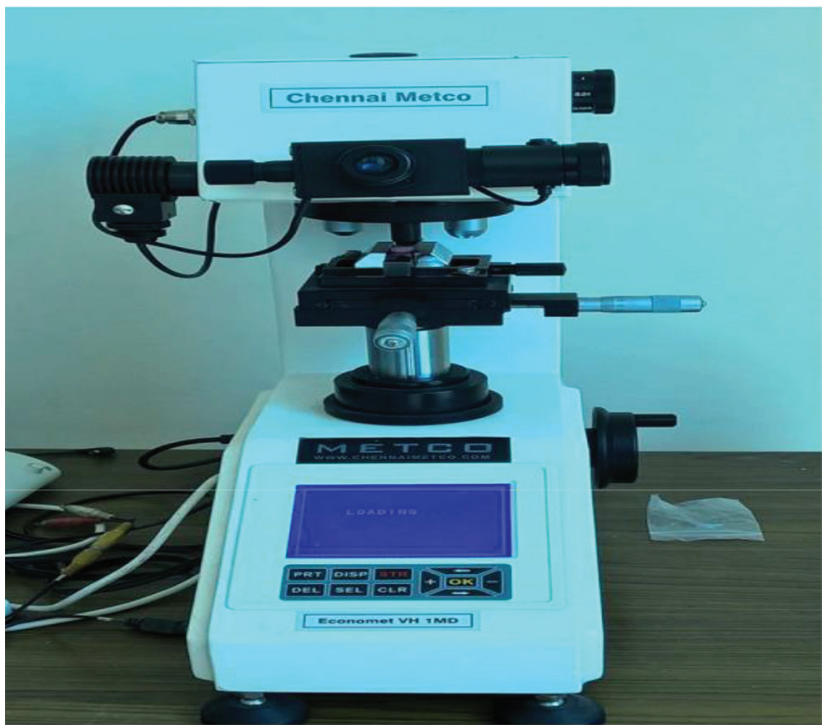

Fig. 5 Knoop hardness tester. 
A thin layer of petrolatum jelly was applied with camel hair brush on the replica of die to serve as a releasing agent for retrievability. All provisional crowns (each of the four materials) were fabricated directly on the stainless steel die and materials were mixed according to the manufacturer's recommendation.

Group A: The polyethyl methacrylate (PEMA) powder (Tempron) was saturated with liquid monomer and hand mixed for 20 to 30 seconds. The powder/liquid ratio as recommended by the manufactures is $1.0 \mathrm{~g} / 0.5 \mathrm{~mL}$ (up to the first gradation on the powder measure and the first gradation on the liquid pipette supplied by the manufacturer). To minimize the shrinkage, use as little liquid as possible. The uniform mix of the material was poured in the matrix and allowed to become matt finished before being placed over the replica. Setting time of the material was 3 to 4 minutes at room temperature. Before it fully sets, the crowns were dipped in and out of water simultaneously several times to prevent shrinkage. Temperature of water bath was kept variable at 20,30, and 40 degrees as per the need of our study (-Fig. 6).

Group B and C: Each bis-acryl material (Protemp 4 and Systemp.c\&b) was dispensed according to manufacturer's instructions from a cartridge through a mixing tip using a dispensing gun and then placed in similar manner onto simulating stainless steel die having prepared and unprepared tooth ( - Fig. 6).

Group D: The polymethyl methacrylate (PMMA) powder (SC-10) was saturated with liquid monomer and hand mixed for 1 minute. The powder/liquid ratio as recommended by the manufactures was $1.0 \mathrm{~g} / 0.5 \mathrm{~mL}$. To minimize the shrinkage only required amount of liquid was used. The uniform mix of the material was poured in the matrix and allowed to become matt finished before being placed over the replica. Before the material was fully set, it was dipped in and out of water several times to prevent shrinkage. Immersion time and temperature were changed as per the criteria of study at 5 and 10 minutes for 20, 30, and 40 degrees (-Fig. 6 ).

\section{Immersion Protocol}

Final polymerization of the samples was then continued in water bath with Equistat at different water temperatures of 20,30 , and 40 degrees. For each sample, the duration of immersion was continued for 5 and 10 minutes, respectively.

\section{Testing of Samples for Marginal Accuracy}

The 240 specimens were then seated on the stainless-steel die which simulated the prepared tooth and evaluated the marginal gap ( - Fig. 7). Each sample was placed under travelling stereoscopic microscope (20x magnification) and photographed (Nikon camera, Nikon Corp.; - Fig. 8). The image analyzing

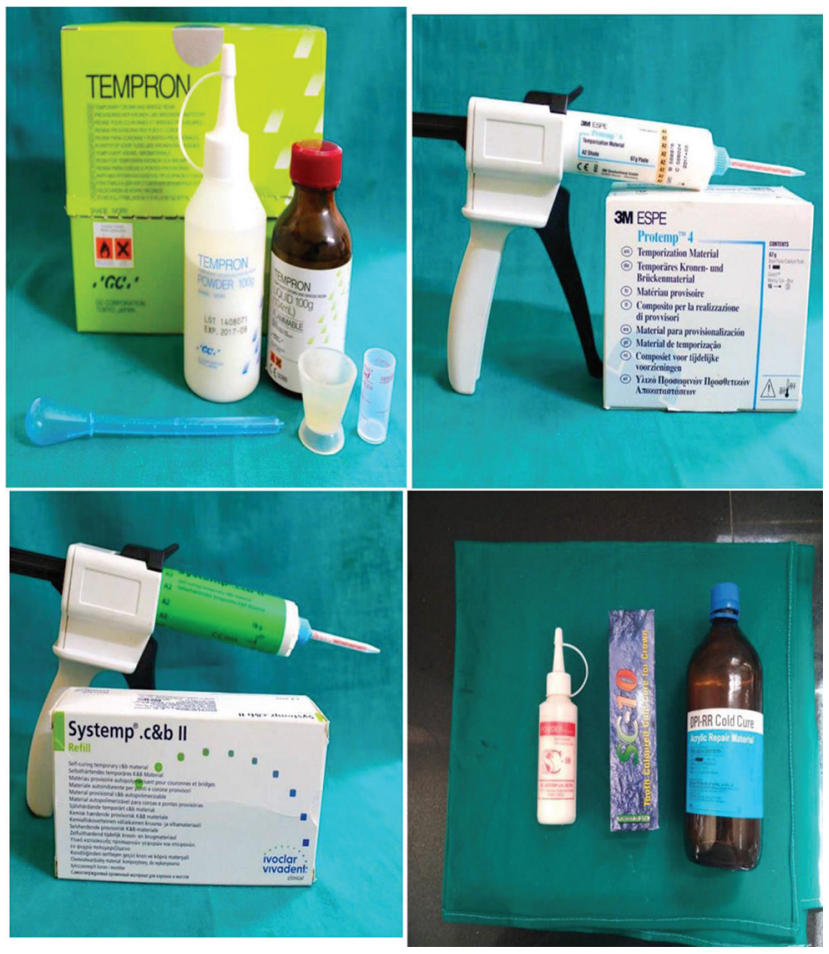

Fig. 6 Four different types of materials used.

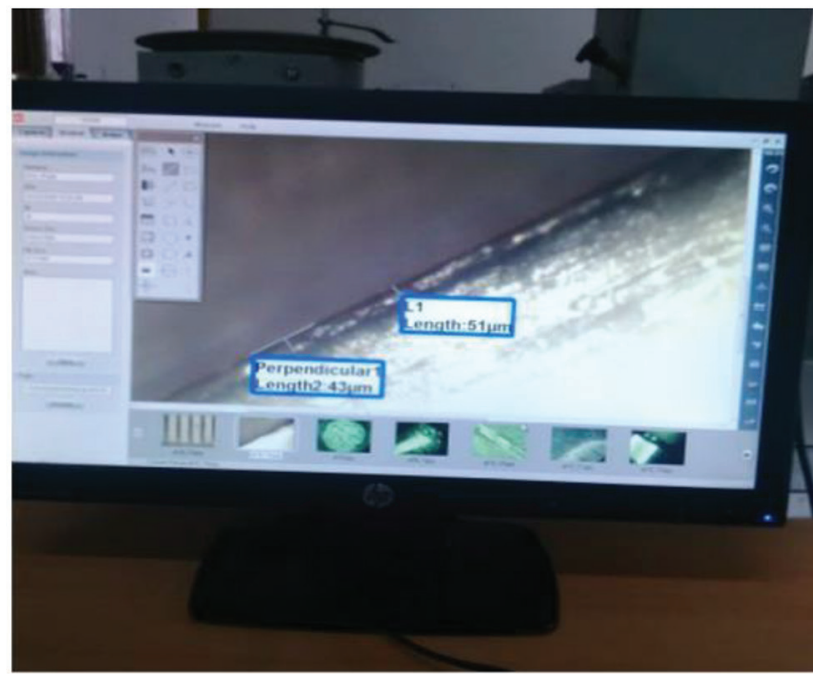

Fig. 7 Digitally checking of marginal discrepancy on stereomicroscope.

software (Image J) was then used to measure the distance, by drawing a parallel line from the crown margins and prepared

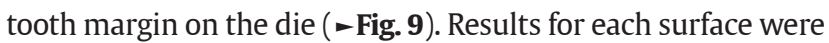
obtained, and the average of three surfaces was calculated.

\section{Testing of Samples for Microhardness}

After evaluating the marginal gap, each sample was placed under the hardness testing procedure. Knoop hardness 


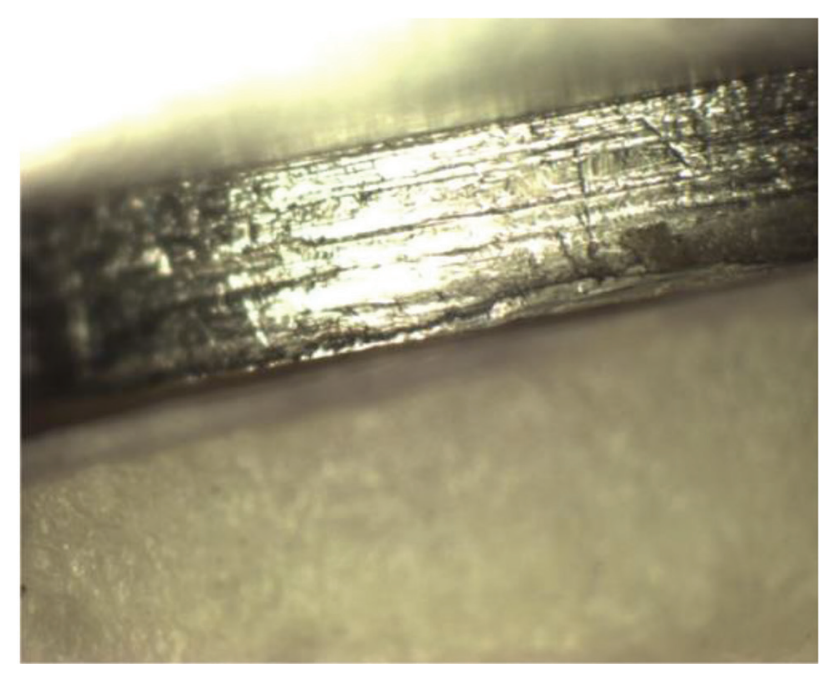

Fig. 8 Marginal discrepancy seen on stereomicroscope.

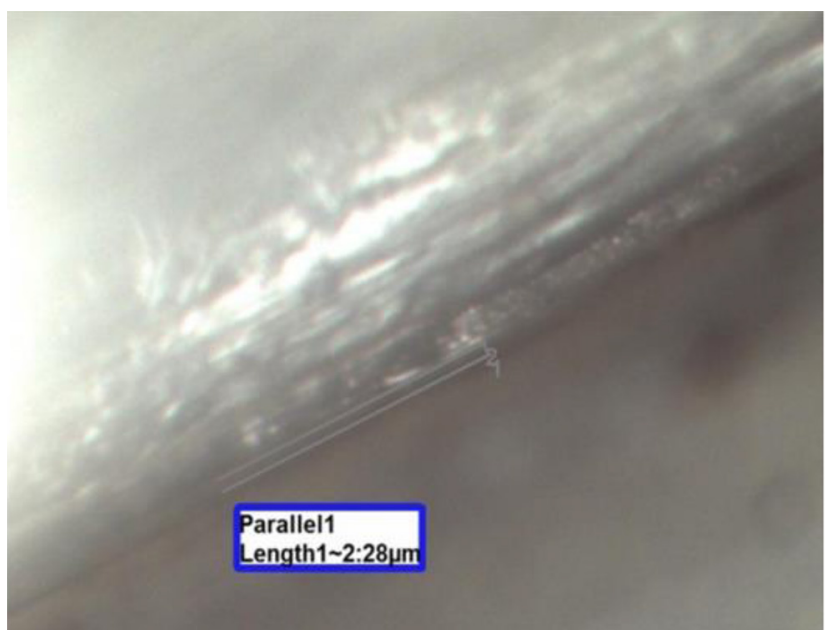

Fig. 9 Marginal discrepancy on stereo microscope between crown margin and finish line. was measured using a microhardness tester (Chennai Metco), with a 10-g indenter load. The microhardness tester has a diamond tip, which penetrates the specimen with a 10 -g load for 10 seconds. When the microhardness tester was activated, the rhomboidal cutting tip presses the specimen surface generating a rhomboidal-shaped geometric figure which could be visualized under magnification by the contrast between the indented surface and the specimen surface. The rhomboid cutting tip allowed to determine the superficial microhardness by the measurement of its major diagonal, which was subjected to a mathematical equation to obtain the results. The microhardness tester automatically performs calculations. The specimen's surface was divided into three parts and one indentation was made in the center of each part for all the specimens.

\section{Results}

The study was subjected to statistical analysis, to know the statistical significance, of the effect of difference in time and temperature changes at the time of final polymerization on surface microhardness and marginal integrity of four different provisional restorative materials.

Two-way analysis of variance (ANOVA) test was used for intergroup comparison and descriptive statistics for mean and standard deviation.

\section{Marginal Discrepancy}

Marginal discrepancy is shown in - Table 1 (-Fig. 10) for Tempron, -Table 2 (-Fig. 11) for Protemp 4, - Table 3 (-Fig. 12) for Telieo Systemp.c\&b, and -Table 4 (-Fig. 13) for SC-10.

Intergroup comparison is shown in - Table $\mathbf{5}$.

Table 1 Comparison of marginal gap in Tempron at different time and temperature

\begin{tabular}{|l|c|l|l|l|l|l|c|c|c|}
\hline & $N$ & Mean & $\begin{array}{l}\text { Std. } \\
\text { deviation }\end{array}$ & $\begin{array}{l}\text { Std. } \\
\text { error }\end{array}$ & Minimum & Maximum & F-value & $p$-Value & $\begin{array}{l}\text { Duncan } \\
\text { grouping }\end{array}$ \\
\hline $\begin{array}{l}20^{\circ} \mathrm{C} \text { for } \\
5 \mathrm{~min}\end{array}$ & 10 & 25.80 & 4.34 & 1.37 & 20.00 & 33.00 & 3.313 & 0.011 & $\mathrm{~B}$ \\
\hline $\begin{array}{l}20^{\circ} \mathrm{C} \text { for } \\
10 \mathrm{~min}\end{array}$ & 10 & 24.10 & 3.92 & 1.24 & 19.00 & 30.00 & $\mathrm{~A}$ \\
\hline $\begin{array}{l}30^{\circ} \mathrm{C} \text { for } \\
10 \mathrm{~min}\end{array}$ & 10 & 26.90 & 5.08 & 1.60 & 20.00 & 33.00 & & $\mathrm{~B}$ \\
\hline $\begin{array}{l}30^{\circ} \mathrm{C} \text { for } \\
10 \mathrm{~min}\end{array}$ & 10 & 25.80 & 4.28 & 1.35 & 20.00 & 33.00 & & $\mathrm{~B}$ \\
\hline $\begin{array}{l}40^{\circ} \mathrm{C} \text { for } \\
5 \mathrm{~min}\end{array}$ & 10 & 21.10 & 2.64 & 0.83 & 18.00 & 25.00 & & \\
\hline $\begin{array}{l}40^{\circ} \mathrm{C} \text { for } \\
10 \mathrm{~min}\end{array}$ & 10 & 21.80 & 3.88 & 1.22 & 16.00 & 29.00 & & $\mathrm{~A}$ \\
\hline Total & 60 & 24.25 & 4.47 & 0.57 & 16.00 & 33.00 & & \\
\hline
\end{tabular}


30

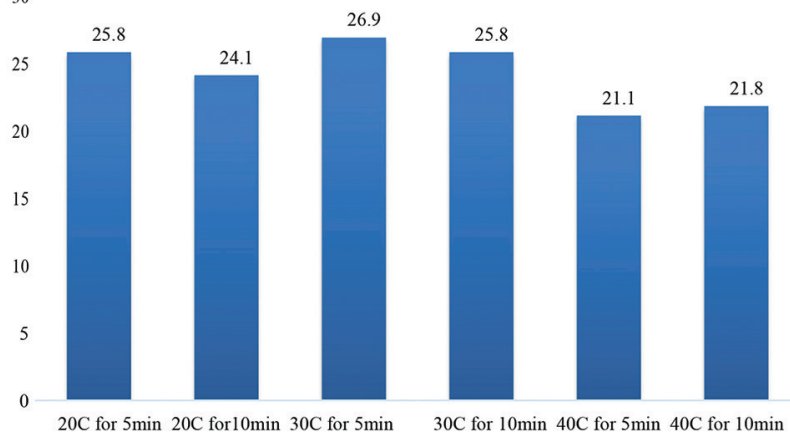

Fig. 10 Comparison of marginal discrepancy in Tempron at different time and temperature.

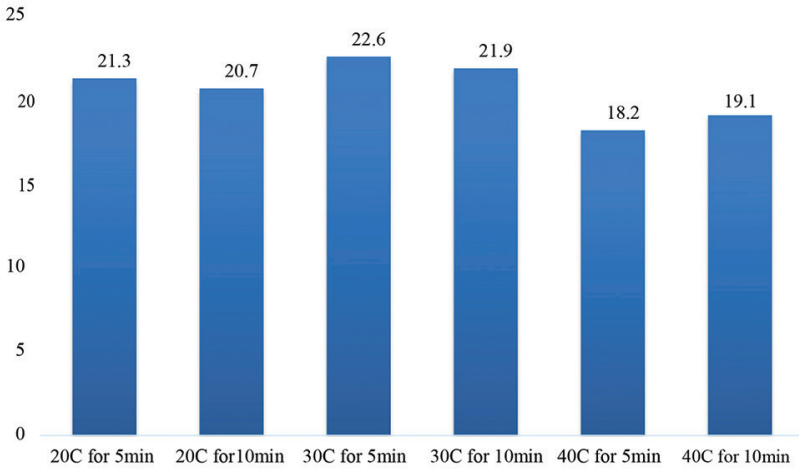

Fig. 11 Comparison of marginal discrepancy in Protemp 4 at different time and temperature.

Table 2 Comparison of marginal gap in Protemp 4 at different time and temperature

\begin{tabular}{|c|c|c|c|c|c|c|c|c|c|}
\hline & $N$ & Mean & $\begin{array}{l}\text { Std. } \\
\text { deviation }\end{array}$ & $\begin{array}{l}\text { Std. } \\
\text { error }\end{array}$ & Minimum & Maximum & $F$-value & $p$-Value & $\begin{array}{l}\text { Duncan } \\
\text { grouping }\end{array}$ \\
\hline $\begin{array}{l}20^{\circ} \mathrm{C} \text { for } \\
5 \mathrm{~min}\end{array}$ & 10 & 21.30 & 3.05 & 0.96 & 18.00 & 28.00 & 3.313 & 0.011 & B \\
\hline $\begin{array}{l}20^{\circ} \mathrm{C} \text { for } \\
10 \mathrm{~min}\end{array}$ & 10 & 20.70 & 2.54 & 0.80 & 18.00 & 25.00 & & & A \\
\hline $\begin{array}{l}30^{\circ} \mathrm{C} \text { for } \\
5 \mathrm{~min}\end{array}$ & 10 & 22.60 & 3.68 & 1.16 & 18.00 & 30.00 & & & B \\
\hline $\begin{array}{l}30^{\circ} \mathrm{C} \text { for } \\
10 \mathrm{~min}\end{array}$ & 10 & 21.90 & 2.92 & 0.92 & 18.00 & 28.00 & & & B \\
\hline $\begin{array}{l}40^{\circ} \mathrm{C} \text { for } \\
5 \mathrm{~min}\end{array}$ & 10 & 18.20 & 2.09 & 0.66 & 14.00 & 21.00 & & & A \\
\hline $\begin{array}{l}40^{\circ} \mathrm{C} \text { for } \\
10 \mathrm{~min}\end{array}$ & 10 & 19.10 & 2.60 & 0.82 & 14.00 & 23.00 & & & A \\
\hline Total & 60 & 20.63 & 3.14 & 0.40 & 14.00 & 30.00 & & & \\
\hline
\end{tabular}

Table 3 Comparison of marginal gap in system C \& B at different time and temperature

\begin{tabular}{|c|c|c|c|c|c|c|c|c|c|}
\hline & $N$ & Mean & $\begin{array}{l}\text { Std. } \\
\text { deviation }\end{array}$ & $\begin{array}{l}\text { Std. } \\
\text { error }\end{array}$ & Minimum & Maximum & F-value & $p$-Value & $\begin{array}{l}\text { Duncan } \\
\text { grouping }\end{array}$ \\
\hline $\begin{array}{l}20^{\circ} \mathrm{C} \text { for } \\
5 \mathrm{~min}\end{array}$ & 10 & 54.50 & 6.83 & 2.16 & 44.00 & 65.00 & 19.692 & $<0.001$ & B \\
\hline $\begin{array}{l}20^{\circ} \mathrm{C} \text { for } \\
10 \mathrm{~min}\end{array}$ & 10 & 54.30 & 3.77 & 1.19 & 50.00 & 60.00 & & & B \\
\hline $\begin{array}{l}30^{\circ} \mathrm{C} \text { for } \\
5 \mathrm{~min}\end{array}$ & 10 & 55.40 & 7.35 & 2.32 & 48.00 & 66.00 & & & B \\
\hline $\begin{array}{l}30^{\circ} \mathrm{C} \text { for } \\
10 \mathrm{~min}\end{array}$ & 10 & 55.40 & 6.29 & 1.98 & 48.00 & 65.00 & & & B \\
\hline $\begin{array}{l}40^{\circ} \mathrm{C} \text { for } \\
5 \mathrm{~min}\end{array}$ & 10 & 38.00 & 5.96 & 1.88 & 30.00 & 51.00 & & & A \\
\hline $\begin{array}{l}40^{\circ} \mathrm{C} \text { for } \\
10 \mathrm{~min}\end{array}$ & 10 & 38.30 & 6.20 & 1.96 & 32.00 & 52.00 & & & A \\
\hline Total & 60 & 49.31 & 9.92 & 1.28 & 30.00 & 66.00 & & & \\
\hline
\end{tabular}




\section{Microhardness}

Microhardness is shown in - Table 6 ( - Fig. 14) for Tempron, -Table 7 (-Fig. 15) for Protemp 4, - Table 8 (-Fig. 16) for Telieo Systemp. c\&b, and - Table 9 (-Fig. 17) for SC10. Intergroup comparison is shown in - Table $\mathbf{1 0}$.

\section{Discussion}

The present "in vitro" study was conducted to evaluate the marginal adaptation and microhardness of four different commercially available provisional restorative materials when dipped into water at different temperatures for different time intervals.

Margin fit of provisional crowns has been investigated by many researchers. The results depended on the design of a master die, the amount of resin, the technique used, and the type of the resin. ${ }^{11}$

Though the current data could not be compared directly with other investigators, the mean marginal discrepancies of

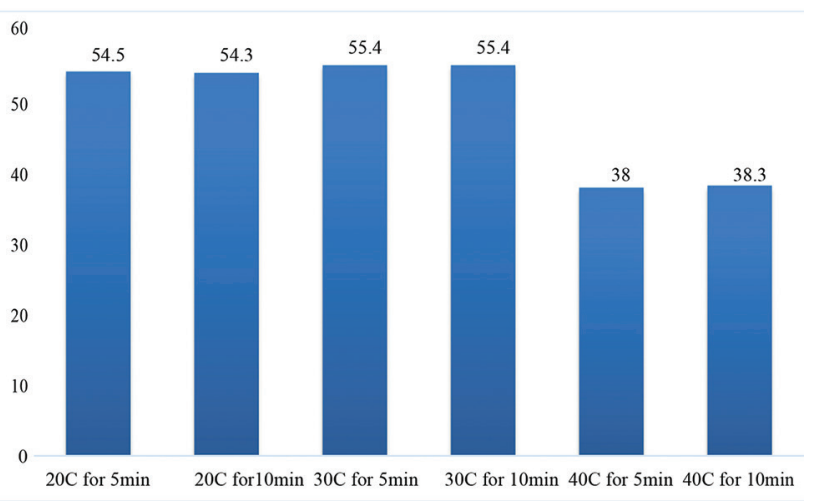

Fig. 12 Comparison of marginal discrepancy in Systemp.c\&b at different time and temperature.
bis-GMA (group B) at 20,30 , and $40^{\circ} \mathrm{C}$ for 5 and 10 minutes in water were smaller than the results of other group. Clinically to get a good marginal adaptation the provisional restoration can be readjusted and relined for number of times. There was very minute difference found in marginal fit between 20 and $30^{\circ} \mathrm{C}$. Polymerization increases in warmer water and it is recommended that for better marginal fit polymerization should be performed at $30^{\circ} \mathrm{C}$. However, as recommended by manufacturer's instruction it should be store at $25^{\circ} \mathrm{C}$. But in this study, it was seen that the least marginal gap was at 40 degrees for 5 minutes in bis-GMA which was $18.2 \mu \mathrm{m}$.

Reason for poor marginal fit at high temperature is due to vaporization of free monomer. At high temperature there is complete polymerization so more shrinkage and more dimensional changes. ${ }^{11}$ Even in cold water between 0 and $10^{\circ} \mathrm{C}$ there is delayed polymerization and poor marginal fit. ${ }^{12}$

The mean gap formation for all the bis-acryl composite materials was comparable (Protemp 4 and Systemp.c\&b); however, PEMA (Tempron) and PMMA (SC-10) had

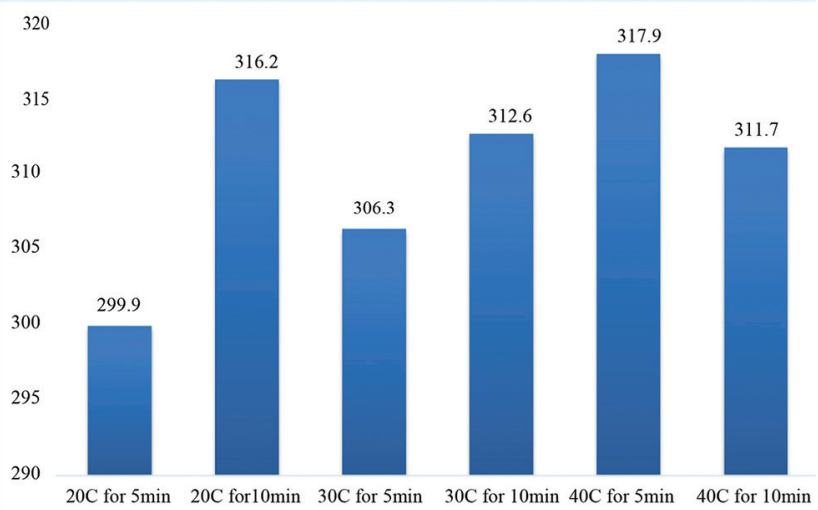

Fig. 13 Comparison of marginal discrepancy in SC 10 at different time and temperature.

Table 4 Comparison of marginal gap in SC10 at different time and temperature

\begin{tabular}{|c|c|c|c|c|c|c|c|c|c|}
\hline & $N$ & Mean & $\begin{array}{l}\text { Std. } \\
\text { deviation }\end{array}$ & $\begin{array}{l}\text { Std. } \\
\text { error }\end{array}$ & Minimum & Maximum & $F$-value & $p$-Value & $\begin{array}{l}\text { Duncan } \\
\text { grouping }\end{array}$ \\
\hline $\begin{array}{l}20^{\circ} \mathrm{C} \text { for } \\
5 \mathrm{~min}\end{array}$ & 10 & 299.90 & 31.98 & 10.11 & 228.00 & 337.00 & 0.993 & 0.431 & A \\
\hline $\begin{array}{l}20^{\circ} \mathrm{C} \text { for } \\
10 \mathrm{~min}\end{array}$ & 10 & 316.20 & 14.72 & 4.65 & 295.00 & 338.00 & & & A \\
\hline $\begin{array}{l}30^{\circ} \mathrm{C} \text { for } \\
5 \mathrm{~min}\end{array}$ & 10 & 306.30 & 20.27 & 6.41 & 283.00 & 337.00 & & & A \\
\hline $\begin{array}{l}30^{\circ} \mathrm{C} \text { for } \\
10 \mathrm{~min}\end{array}$ & 10 & 312.60 & 18.26 & 5.77 & 290.00 & 338.00 & & & A \\
\hline $\begin{array}{l}40^{\circ} \mathrm{C} \text { for } \\
5 \mathrm{~min}\end{array}$ & 10 & 317.90 & 21.52 & 6.80 & 285.00 & 364.00 & & & A \\
\hline $\begin{array}{l}40^{\circ} \mathrm{C} \text { for } \\
10 \mathrm{~min}\end{array}$ & 10 & 311.70 & 15.60 & 4.93 & 295.00 & 338.00 & & & A \\
\hline Total & 60 & 310.76 & 21.17 & 2.73 & 228.00 & 364.00 & & & \\
\hline
\end{tabular}


122 Effect of Water Temperature and Duration of Immersion on Provisional Restoration Verma et al.

Table 5 Intergroup comparison of marginal gap

\begin{tabular}{|c|c|c|c|c|c|c|c|c|}
\hline \multicolumn{9}{|c|}{ Descriptives } \\
\hline \multirow[t]{2}{*}{ Marginal gap } & \multirow[t]{2}{*}{$N$} & \multirow[t]{2}{*}{ Mean } & \multirow{2}{*}{$\begin{array}{l}\text { Std. } \\
\text { deviation }\end{array}$} & \multirow[t]{2}{*}{ Std. error } & \multicolumn{2}{|c|}{$95 \% \mathrm{Cl}$ for mean } & \multirow[t]{2}{*}{ Minimum } & \multirow[t]{2}{*}{ Maximum } \\
\hline & & & & & $\begin{array}{l}\text { Lower } \\
\text { bound }\end{array}$ & $\begin{array}{l}\text { Upper } \\
\text { bound }\end{array}$ & & \\
\hline Group $\mathrm{A}$ at $20^{\circ} \mathrm{C}$ for $5 \mathrm{~min}$ & 10 & 25.8000 & 4.34102 & 1.37275 & 22.6946 & 28.9054 & 20.00 & 33.00 \\
\hline Group $\mathrm{A}$ at $20^{\circ} \mathrm{C}$ for $10 \mathrm{~min}$ & 10 & 24.1000 & 3.92853 & 1.24231 & 21.2897 & 26.9103 & 19.00 & 30.00 \\
\hline Group $\mathrm{A}$ at $30^{\circ} \mathrm{C}$ for $5 \mathrm{~min}$ & 10 & 26.9000 & 5.08702 & 1.60866 & 23.2610 & 30.5390 & 20.00 & 33.00 \\
\hline group $\mathrm{A}$ at $30^{\circ} \mathrm{C}$ for $10 \mathrm{~min}$ & 10 & 25.8000 & 4.28952 & 1.35647 & 22.7315 & 28.8685 & 20.00 & 33.00 \\
\hline Group $\mathrm{A}$ at $40^{\circ} \mathrm{C}$ for $5 \mathrm{~min}$ & 10 & 21.1000 & 2.64365 & 0.83600 & 19.2088 & 22.9912 & 18.00 & 25.00 \\
\hline Group $\mathrm{A}$ at $40^{\circ} \mathrm{C}$ for $10 \mathrm{~min}$ & 10 & 21.8000 & 3.88158 & 1.22746 & 19.0233 & 24.5767 & 16.00 & 29.00 \\
\hline Group B at $20^{\circ} \mathrm{C}$ for $5 \mathrm{~min}$ & 10 & 21.3000 & 3.05687 & 0.96667 & 19.1132 & 23.4868 & 18.00 & 28.00 \\
\hline Group $\mathrm{B}$ at $20^{\circ} \mathrm{C}$ for $10 \mathrm{~min}$ & 10 & 20.7000 & 2.54078 & 0.80346 & 18.8824 & 22.5176 & 18.00 & 25.00 \\
\hline Group B at $30^{\circ} \mathrm{C}$ for 5 min & 10 & 22.6000 & 3.68782 & 1.16619 & 19.9619 & 25.2381 & 18.00 & 30.00 \\
\hline Group $\mathrm{B}$ at $30^{\circ} \mathrm{C}$ for $10 \mathrm{~min}$ & 10 & 21.9000 & 2.92309 & 0.92436 & 19.8089 & 23.9911 & 18.00 & 28.00 \\
\hline Group B at $40^{\circ} \mathrm{C}$ for $5 \mathrm{~min}$ & 10 & 18.2000 & 2.09762 & 0.66332 & 16.6995 & 19.7005 & 14.00 & 21.00 \\
\hline Group $\mathrm{B}$ at $40^{\circ} \mathrm{C}$ for $10 \mathrm{~min}$ & 10 & 19.1000 & 2.60128 & 0.82260 & 17.2392 & 20.9608 & 14.00 & 23.00 \\
\hline Group $\mathrm{C}$ at $20^{\circ} \mathrm{C}$ for $5 \mathrm{~min}$ & 10 & 54.5000 & 6.83537 & 2.16153 & 49.6103 & 59.3897 & 44.00 & 65.00 \\
\hline Group $\mathrm{C}$ at $20^{\circ} \mathrm{C}$ for $10 \mathrm{~min}$ & 10 & 54.3000 & 3.77271 & 1.19304 & 51.6012 & 56.9988 & 50.00 & 60.00 \\
\hline Group $\mathrm{C}$ at $30^{\circ} \mathrm{C}$ for $5 \mathrm{~min}$ & 10 & 55.4000 & 7.35149 & 2.32475 & 50.1411 & 60.6589 & 48.00 & 66.00 \\
\hline Group $\mathrm{C}$ at $30^{\circ} \mathrm{C}$ for $10 \mathrm{~min}$ & 10 & 55.4000 & 6.29285 & 1.98997 & 50.8984 & 59.9016 & 48.00 & 65.00 \\
\hline Group $\mathrm{C}$ at $40^{\circ} \mathrm{C}$ for $5 \mathrm{~min}$ & 10 & 38.0000 & 5.96285 & 1.88562 & 33.7344 & 42.2656 & 30.00 & 51.00 \\
\hline Group $\mathrm{C}$ at $40^{\circ} \mathrm{C}$ for $10 \mathrm{~min}$ & 10 & 38.3000 & 6.20125 & 1.96101 & 33.8639 & 42.7361 & 32.00 & 52.00 \\
\hline Group $\mathrm{D}$ at $20^{\circ} \mathrm{C}$ for $5 \mathrm{~min}$ & 10 & 299.9000 & 31.98767 & 10.11539 & 277.0174 & 322.7826 & 228.00 & 337.00 \\
\hline Group $\mathrm{D}$ at $20^{\circ} \mathrm{C}$ for $10 \mathrm{~min}$ & 10 & 316.2000 & 14.72564 & 4.65666 & 305.6659 & 326.7341 & 295.00 & 338.00 \\
\hline Group D at $30^{\circ} \mathrm{C}$ for $5 \mathrm{~min}$ & 10 & 306.3000 & 20.27067 & 6.41015 & 291.7992 & 320.8008 & 283.00 & 337.00 \\
\hline Group $\mathrm{D}$ at $30^{\circ} \mathrm{C}$ for $10 \mathrm{~min}$ & 10 & 312.6000 & 18.26472 & 5.77581 & 299.5342 & 325.6658 & 290.00 & 338.00 \\
\hline Group $\mathrm{D}$ at $40^{\circ} \mathrm{C}$ for $5 \mathrm{~min}$ & 10 & 317.9000 & 21.52750 & 6.80759 & 302.5002 & 333.2998 & 285.00 & 364.00 \\
\hline Group $\mathrm{D}$ at $40^{\circ} \mathrm{C}$ for $10 \mathrm{~min}$ & 10 & 311.7000 & 15.60662 & 4.93525 & 300.5357 & 322.8643 & 295.00 & 338.00 \\
\hline Total & 240 & 101.2417 & 122.30985 & 7.89507 & 85.6889 & 116.7945 & 14.00 & 364.00 \\
\hline & & & & ANOVA & & & & \\
\hline Marginal gap & & Sum of square & & $\mathrm{d} f$ & $\mathrm{Me}$ & square & $F$ & Sig. \\
\hline Between groups & & 3547738.983 & & 23 & 15 & 9.521 & 1205.903 & 0.000 \\
\hline Within groups & & 27629.000 & & 216 & 12 & & & \\
\hline Total & & 3575367.983 & & 239 & & & & \\
\hline
\end{tabular}

Table 6 Comparison of microhardness in Tempron at different time and temperature

\begin{tabular}{|l|l|l|l|l|l|l|l|l|l|}
\hline & $N$ & Mean & Std. deviation & $\begin{array}{l}\text { Std. } \\
\text { error }\end{array}$ & Minimum & Maximum & $F$-value & $p$-Value & $\begin{array}{l}\text { Duncan } \\
\text { grouping }\end{array}$ \\
\hline $\begin{array}{l}20^{\circ} \mathrm{C} \text { for } \\
5 \mathrm{~min}\end{array}$ & 10 & 12.60 & 1.71 & 0.54 & 10.00 & 15.00 & 1.348 & 0.259 & $\mathrm{~A}$ \\
\hline $\begin{array}{l}20^{\circ} \mathrm{C} \text { for } \\
10 \mathrm{~min}\end{array}$ & 10 & 12.50 & 1.58 & 0.50 & 10.00 & 15.00 & & & $\mathrm{~A}$ \\
\hline $\begin{array}{l}30^{\circ} \mathrm{C} \text { for } \\
5 \mathrm{~min}\end{array}$ & 10 & 12.10 & 1.44 & 0.45 & 10.00 & 15.00 & & & $\mathrm{~A}$ \\
\hline $\begin{array}{l}30^{\circ} \mathrm{C} \text { for } \\
10 \mathrm{~min}\end{array}$ & 10 & 12.60 & 1.42 & 0.45 & 10.00 & 15.00 & & & $\mathrm{~A}$ \\
\hline $\begin{array}{l}40^{\circ} \mathrm{C} \text { for } \\
5 \mathrm{~min}\end{array}$ & 10 & 13.40 & 2.06 & 0.65 & 10.00 & 16.00 & & & $\mathrm{~A}$ \\
\hline $\begin{array}{l}40^{\circ} \mathrm{C} \text { for } \\
10 \mathrm{~min}\end{array}$ & 10 & 13.90 & 2.42 & 0.76 & 10.00 & 17.00 & & & $\mathrm{~A}$ \\
\hline Total & 60 & 12.85 & 1.83 & 0.23 & 10.00 & 17.00 & & & \\
\hline
\end{tabular}




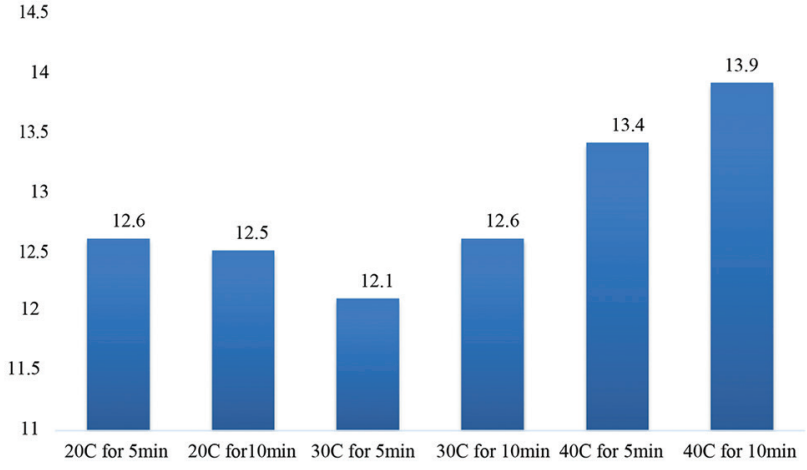

Fig. 14 Comparison of surface microhardness in Tempron at different time and temperature.

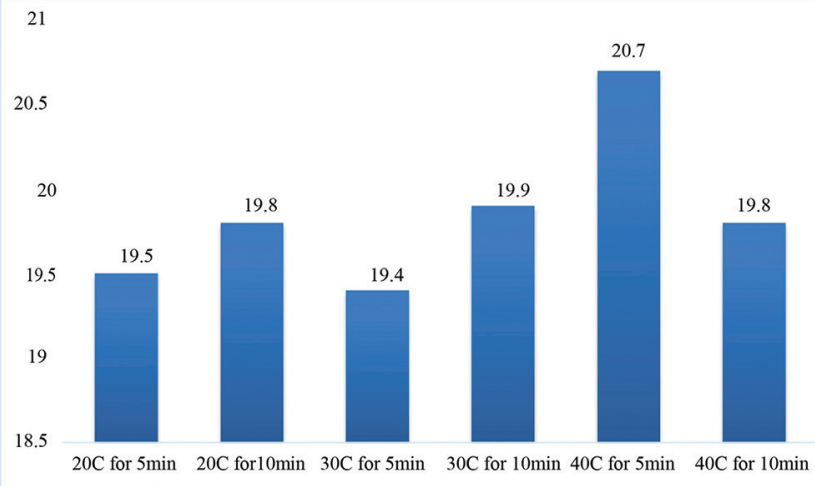

Fig. 15 Comparison of surface microhardness in Protemp 4 at different time and temperature.

Table 7 Comparison of micro hardness in Protemp 4 at different time and temperature

\begin{tabular}{|l|l|l|l|l|l|l|l|l|l|l|}
\hline & & $N$ & Mean & $\begin{array}{l}\text { Std. } \\
\text { deviation }\end{array}$ & $\begin{array}{l}\text { Std. } \\
\text { error }\end{array}$ & Minimum & Maximum & F-value & $p$-Value & $\begin{array}{l}\text { Duncan } \\
\text { grouping }\end{array}$ \\
\hline $\begin{array}{l}20^{\circ} \mathrm{C} \text { for } \\
5 \mathrm{~min}\end{array}$ & 10 & 19.50 & 1.90 & 0.60 & 17.00 & 24.00 & 0.674 & 0.645 & $\mathrm{~A}$ \\
\hline $\begin{array}{l}20^{\circ} \mathrm{C} \text { for } \\
10 \mathrm{~min}\end{array}$ & 10 & 19.80 & 2.20 & 0.69 & 17.00 & 24.00 & & & $\mathrm{~A}$ & \\
\hline $\begin{array}{l}30^{\circ} \mathrm{C} \text { for } \\
5 \mathrm{~min}\end{array}$ & 10 & 19.40 & 1.26 & 0.40 & 18.00 & 22.00 & & & $\mathrm{~A}$ & \\
\hline $\begin{array}{l}30^{\circ} \mathrm{C} \text { for } \\
10 \mathrm{~min}\end{array}$ & 10 & 19.90 & 1.72 & 0.54 & 18.00 & 24.00 & & & $\mathrm{~A}$ & \\
\hline $\begin{array}{l}40^{\circ} \mathrm{C} \text { for } \\
5 \mathrm{~min}\end{array}$ & 10 & 20.70 & 1.33 & 0.42 & 19.00 & 23.00 & & & $\mathrm{~A}$ & \\
\hline $\begin{array}{l}40^{\circ} \mathrm{C} \text { for } \\
10 \mathrm{~min}\end{array}$ & 10 & 19.80 & 1.98 & 0.62 & 17.00 & 24.00 & & & $\mathrm{~A}$ & \\
\hline Total & 60 & 19.85 & 1.74 & 0.22 & 17.00 & 24.00 & & & \\
\hline
\end{tabular}

Table 8 Comparison of microhardness in system C and B at different time and temperature

\begin{tabular}{|c|c|c|c|c|c|c|c|c|c|}
\hline & $N$ & Mean & Std. deviation & $\begin{array}{l}\text { Std. } \\
\text { error }\end{array}$ & Minimum & Maximum & $F$-value & $p$-Value & $\begin{array}{l}\text { Duncan } \\
\text { grouping }\end{array}$ \\
\hline $\begin{array}{l}20^{\circ} \mathrm{C} \text { for } \\
5 \mathrm{~min}\end{array}$ & 10 & 16.10 & 1.96 & 0.62 & 14.00 & 20.00 & 4.223 & 0.00 & A \\
\hline $\begin{array}{l}20^{\circ} \mathrm{C} \text { for } \\
10 \mathrm{~min}\end{array}$ & 10 & 16.80 & 1.68 & 0.53 & 15.00 & 20.00 & & & A \\
\hline $\begin{array}{l}30^{\circ} \mathrm{C} \text { for } \\
5 \mathrm{~min}\end{array}$ & 10 & 17.30 & 1.82 & 0.57 & 15.00 & 20.00 & & & A \\
\hline $\begin{array}{l}30^{\circ} \mathrm{C} \text { for } \\
10 \mathrm{~min}\end{array}$ & 10 & 17.50 & 1.71 & 0.54 & 15.00 & 20.00 & & & A \\
\hline $\begin{array}{l}40^{\circ} \mathrm{C} \text { for } \\
5 \mathrm{~min}\end{array}$ & 10 & 17.90 & 1.91 & 0.60 & 15.00 & 20.00 & & & A \\
\hline $\begin{array}{l}40^{\circ} \mathrm{C} \text { for } \\
10 \mathrm{~min}\end{array}$ & 10 & 19.60 & 1.83 & 0.58 & 17.00 & 22.00 & & & B \\
\hline Total & 60 & 17.53 & 2.06 & 0.26 & 14.00 & 22.00 & & & \\
\hline
\end{tabular}


25

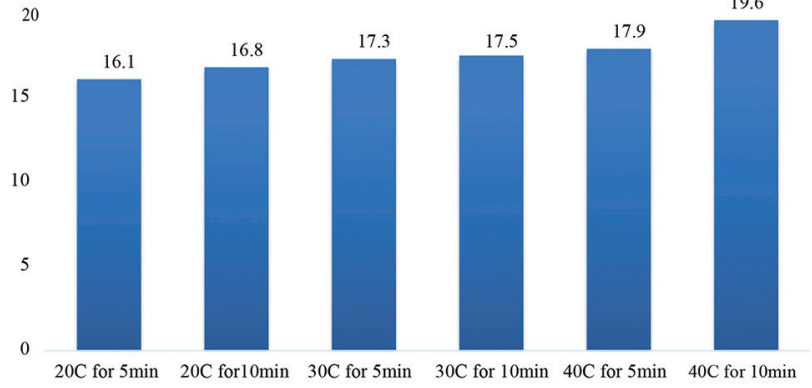

Fig. 16 Comparison of surface microhardness in Systemp.c\&b at different time and temperature.

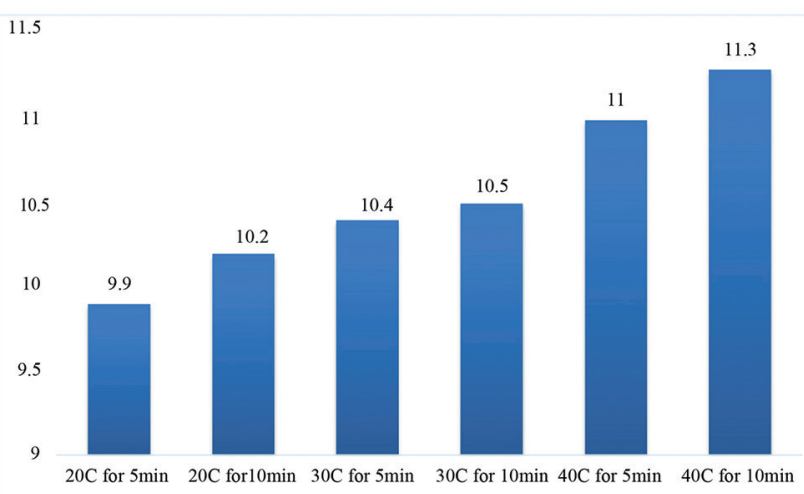

Fig. 17 Comparison of surface microhardness in SC10 at different time and temperature.

Table 9 Comparison of microhardness in SC10 at different time and temperature

\begin{tabular}{|l|l|l|l|l|l|l|l|l|l|}
\hline & $N$ & Mean & Std. deviation & $\begin{array}{l}\text { Std. } \\
\text { error }\end{array}$ & Minimum & Maximum & F-value & $p$-Value & $\begin{array}{l}\text { Duncan } \\
\text { grouping }\end{array}$ \\
\hline $\begin{array}{l}20^{\circ} \mathrm{C} \text { for } \\
5 \mathrm{~min}\end{array}$ & 10 & 9.90 & 1.66 & 0.52 & 7.00 & 12.00 & 0.871 & 0.507 & $\mathrm{~A}$ \\
\hline $\begin{array}{l}20^{\circ} \mathrm{C} \text { for } \\
10 \mathrm{~min}\end{array}$ & 10 & 10.20 & 1.31 & 0.41 & 8.00 & 12.00 & & & $\mathrm{~A}$ \\
\hline $\begin{array}{l}30^{\circ} \mathrm{C} \text { for } \\
5 \mathrm{~min}\end{array}$ & 10 & 10.40 & 1.42 & 0.45 & 7.00 & 12.00 & & & $\mathrm{~A}$ \\
\hline $\begin{array}{l}30^{\circ} \mathrm{C} \text { for } \\
10 \mathrm{~min}\end{array}$ & 10 & 10.50 & 1.50 & 0.47 & 7.00 & 12.00 & & & $\mathrm{~A}$ \\
\hline $\begin{array}{l}40^{\circ} \mathrm{C} \text { for } \\
5 \mathrm{~min}\end{array}$ & 10 & 11.00 & 2.10 & 0.66 & 7.00 & 14.00 & & & $\mathrm{~A}$ \\
\hline $\begin{array}{l}40^{\circ} \mathrm{C} \text { for } \\
10 \mathrm{~min}\end{array}$ & 10 & 11.30 & 2.26 & 0.71 & 8.00 & 16.00 & & & $\mathrm{~A}$ \\
\hline Total & 60 & 10.55 & 1.74 & 0.22 & 7.00 & 16.00 & & & \\
\hline
\end{tabular}

significantly greater marginal discrepancy. The least marginal gap formation was observed for Protemp 4 and the highest discrepancy was observed for SC-10.

In this study for Group B, it was evaluated that the least mean marginal discrepancy of $18.2 \mu \mathrm{m}$ was evaluated at 40-degree immersion for 5 minutes duration. And the highest mean marginal discrepancy of $22.6 \mu \mathrm{m}$ was seen at 30-degrees immersion temperature for the duration of 5 minutes. For Group A, it was evaluated that the least mean marginal discrepancy of $21.1 \mu \mathrm{m}$ was evaluated at 40 -degrees immersion for 5 minutes duration and the highest mean marginal discrepancy of $26.9 \mu \mathrm{m}$ was seen at 30 degrees immersion temperature for the duration of 5 minutes. For Group C, it was evaluated that the least mean marginal discrepancy of $38.0 \mu \mathrm{m}$ was evaluated at 40-degree immersion for 5- and 10-minutes duration. And the highest mean marginal discrepancy of $55.4 \mu \mathrm{m}$ was seen at 30-degree immersion temperature for the duration of 5 and 10 minutes. For Group D, it was evaluated that the least mean marginal discrepancy of $299.9 \mu \mathrm{m}$ was evaluated at 20-degree immersion for 5-minutes duration. And the highest mean marginal discrepancy of $317.9 \mu \mathrm{m}$ was seen at 40-degrees immersion temperature for the duration of 5 minutes. Using Duncantest the results were compared and statistically analyzed; test revealed that the marginal gap is comparable in 20, 30, and $40^{\circ} \mathrm{C}$ for 5 and 10 minutes which was a significant difference. The ANOVA test revealed a significant difference $(p=0.001)$ in marginal gap at different time and temperature.

According to Adnan et al, bis-acryl resin composite materials had better marginal adaptability as compared with polyethyl methacrylates. ${ }^{13}$ Verma et al also reported that marginal fit of provisional restorations made from the bis-GMA and conventional acrylic resins were better. There was more marginal gap in PMMA. ${ }^{14}$ According to Young et al, it was found that marginal fit was better with bis-acryl composite resin than PMMA. ${ }^{15}$

The surface hardness of a material is affected by strength, proportional limit, ductility, malleability, and resistance to abrasion.

In this study bis-acryl resin composite materials showed better microhardness than conventional methacrylate-type resins. Mechanical strength of bis-acryl composites increases with cross linkage bifunctional acrylates in the base pastes. So, under pressure there was air entrapment thus leading to lower strength. Due to increased inorganic fillers the bisacryl resins had better resistance to abrasion and less polymerization shrinkage. 
Table 10 Intergroup comparison of microhardness

\begin{tabular}{|c|c|c|c|c|c|c|c|c|}
\hline \multicolumn{9}{|c|}{ Descriptives } \\
\hline \multirow[t]{2}{*}{ Microhardness } & \multirow[t]{2}{*}{$N$} & \multirow[t]{2}{*}{ Mean } & \multirow{2}{*}{$\begin{array}{l}\text { Std. } \\
\text { deviation }\end{array}$} & \multirow{2}{*}{$\begin{array}{l}\text { Std. } \\
\text { error }\end{array}$} & \multicolumn{2}{|c|}{$95 \% \mathrm{Cl}$ for mean } & \multirow[t]{2}{*}{ Minimum } & \multirow[t]{2}{*}{ Maximum } \\
\hline & & & & & $\begin{array}{l}\text { Lower } \\
\text { bound }\end{array}$ & Upper bound & & \\
\hline Group $\mathrm{A}$ at $20^{\circ} \mathrm{C}$ for $5 \mathrm{~min}$ & 10 & 12.6000 & 1.71270 & 0.54160 & 11.3748 & 13.8252 & 10.00 & 15.00 \\
\hline Group $\mathrm{A}$ at $20^{\circ} \mathrm{C}$ for $10 \mathrm{~min}$ & 10 & 12.5000 & 1.58114 & 0.50000 & 11.3689 & 13.6311 & 10.00 & 15.00 \\
\hline Group $\mathrm{A}$ at $30^{\circ} \mathrm{C}$ for $5 \mathrm{~min}$ & 10 & 12.1000 & 1.44914 & 0.45826 & 11.0633 & 13.1367 & 10.00 & 15.00 \\
\hline Group $\mathrm{A}$ at $30^{\circ} \mathrm{C}$ for $10 \mathrm{~min}$ & 10 & 12.6000 & 1.42984 & 0.45216 & 11.5772 & 13.6228 & 10.00 & 15.00 \\
\hline Group $\mathrm{A}$ at $40^{\circ} \mathrm{C}$ for $5 \mathrm{~min}$ & 10 & 13.4000 & 2.06559 & 0.65320 & 11.9224 & 14.8776 & 10.00 & 16.00 \\
\hline Group $\mathrm{A}$ at $40^{\circ} \mathrm{C}$ for $10 \mathrm{~min}$ & 10 & 13.9000 & 2.42441 & 0.76667 & 12.1657 & 15.6343 & 10.00 & 17.00 \\
\hline Group B at $20^{\circ} \mathrm{C}$ for 5 min & 10 & 19.5000 & 1.90029 & 0.60093 & 18.1406 & 20.8594 & 17.00 & 24.00 \\
\hline Group B at $20^{\circ} \mathrm{C}$ for $10 \mathrm{~min}$ & 10 & 19.8000 & 2.20101 & 0.69602 & 18.2255 & 21.3745 & 17.00 & 24.00 \\
\hline Group B at $30^{\circ} \mathrm{C}$ for 5 min & 10 & 19.4000 & 1.26491 & 0.40000 & 18.4951 & 20.3049 & 18.00 & 22.00 \\
\hline Group $\mathrm{B}$ at $30^{\circ} \mathrm{C}$ for $10 \mathrm{~min}$ & 10 & 19.9000 & 1.72884 & 0.54671 & 18.6633 & 21.1367 & 18.00 & 24.00 \\
\hline Group $\mathrm{B}$ at $40^{\circ} \mathrm{C}$ for $5 \mathrm{~min}$ & 10 & 20.7000 & 1.33749 & 0.42295 & 19.7432 & 21.6568 & 19.00 & 23.00 \\
\hline Group B at $40^{\circ} \mathrm{C}$ for $10 \mathrm{~min}$ & 10 & 19.8000 & 1.98886 & 0.62893 & 18.3773 & 21.2227 & 17.00 & 24.00 \\
\hline Group $\mathrm{C}$ at $20^{\circ} \mathrm{C}$ for $5 \mathrm{~min}$ & 10 & 16.1000 & 1.96921 & 0.62272 & 14.6913 & 17.5087 & 14.00 & 20.00 \\
\hline Group $\mathrm{C}$ at $20^{\circ} \mathrm{C}$ for $10 \mathrm{~min}$ & 10 & 16.8000 & 1.68655 & 0.53333 & 15.5935 & 18.0065 & 15.00 & 20.00 \\
\hline Group $\mathrm{C}$ at $30^{\circ} \mathrm{C}$ for $5 \mathrm{~min}$ & 10 & 17.3000 & 1.82878 & 0.57831 & 15.9918 & 18.6082 & 15.00 & 20.00 \\
\hline Group $\mathrm{C}$ at $30^{\circ} \mathrm{C}$ for $10 \mathrm{~min}$ & 10 & 17.5000 & 1.71594 & 0.54263 & 16.2725 & 18.7275 & 15.00 & 20.00 \\
\hline Group $\mathrm{C}$ at $40^{\circ} \mathrm{C}$ for $5 \mathrm{~min}$ & 10 & 17.9000 & 1.91195 & 0.60461 & 16.5323 & 19.2677 & 15.00 & 20.00 \\
\hline Group $\mathrm{C}$ at $40^{\circ} \mathrm{C}$ for $10 \mathrm{~min}$ & 10 & 19.6000 & 1.83787 & 0.58119 & 18.2853 & 20.9147 & 17.00 & 22.00 \\
\hline Group D at $20^{\circ} \mathrm{C}$ for $5 \mathrm{~min}$ & 10 & 9.9000 & 1.66333 & 0.52599 & 8.7101 & 11.0899 & 7.00 & 12.00 \\
\hline Group $\mathrm{D}$ at $20^{\circ} \mathrm{C}$ for $10 \mathrm{~min}$ & 10 & 10.2000 & 1.31656 & 0.41633 & 9.2582 & 11.1418 & 8.00 & 12.00 \\
\hline Group D at $30^{\circ} \mathrm{C}$ for $5 \mathrm{~min}$ & 10 & 10.4000 & 1.42984 & 0.45216 & 9.3772 & 11.4228 & 7.00 & 12.00 \\
\hline Group $\mathrm{D}$ at $30^{\circ} \mathrm{C}$ for $10 \mathrm{~min}$ & 10 & 10.5000 & 1.50923 & 0.47726 & 9.4204 & 11.5796 & 7.00 & 12.00 \\
\hline Group $\mathrm{D}$ at $40^{\circ} \mathrm{C}$ for $5 \mathrm{~min}$ & 10 & 11.0000 & 2.10819 & 0.66667 & 9.4919 & 12.5081 & 7.00 & 14.00 \\
\hline Group $\mathrm{D}$ at $40^{\circ} \mathrm{C}$ for $10 \mathrm{~min}$ & 10 & 11.3000 & 2.26323 & 0.71570 & 9.6810 & 12.9190 & 8.00 & 16.00 \\
\hline Total & 240 & 15.1958 & 4.12249 & 0.26611 & 14.6716 & 15.7200 & 7.00 & 24.00 \\
\hline & & & & ANOVA & & & & \\
\hline Marginal gap & & Sum of $\mathrm{s}$ & quares & d & & Mean square & $F$ - Value & Sig. \\
\hline Between groups & & 3369.296 & & 2 & & 146.491 & 45.693 & 0.000 \\
\hline Within groups & & 692.500 & & & & 3.206 & & \\
\hline Total & & 4061.796 & & & & & & \\
\hline
\end{tabular}

When the provisional restorations were fabricated with a material with good wear resistance, the breakage was less and had better prognosis for longer duration of time.

The results for microhardness evaluation showed that the poly(ethyl methacrylate) type resin (Tempron) exhibited significantly lower microhardness than the bis-acryl resin composites (Protemp 4 and Systemp.c\&b) at both time and temperature intervals. bis-GMA materials (Protemp 4 and Systemp.c\&b) demonstrated the highest values of microhardness amongst all groups. All materials showed a statistically significant result.

The result of the present study is in accordance with the study of Diaz-Arnold et al who reported that the hardness of most materials decreased over time and all of the bis-acryl resin composite materials had better microhardness over conventional methyl methacrylate resins. ${ }^{9}$

Within the limitations of this study, the values obtained "in vitro" may not simulate oral environment. According to Kim and Watts, ${ }^{16}$ shrinkage strain at $37^{\circ} \mathrm{C}$ is higher than at $23^{\circ} \mathrm{C}$ room temperature, which might affect the results obtained. Furthermore, for checking the marginal adaptation, specimens were not thermocycled, occlusally loaded, or experimentally aged. Therefore, further research is necessary to precisely correlate the implications of this study.

\section{Conclusion}

An "in vitro" study was undertaken to test the marginal adaptation and surface microhardness of four different commercially available provisional restorative materials. On comparative observation, Protemp 4 showed the lowest marginal discrepancy followed by Tempron, Systemp.c\&b. The highest discrepancy was observed in SC-10. The observations were analyzed statistically and found to be significant according to two-way ANOVA test. 
On subjecting samples for surface microhardness test, the KHN was highest for Protemp 4 followed by Systemp.c\&b and Tempron. SC-by10 (Poly methyl methacrylate) exhibits least surface microhardness.

Hence, the following conclusions were drawn:

The bis-acryl composites material has the least marginal discrepancy in comparison with PEMA and PMMA. The is-acryl composite materials exhibit superior surface microhardness followed by PEMA and PMMA.

\section{Conflictof Interest}

None declared.

\section{References}

1 Rosenstiel SF, Land MF, Fujimoto J, Contemporary Fixed Prosthodontics. 3rd ed. St. Louis: Mosby; 2000 618-630

2 Rakhshan V. Marginal integrity of provisional resin restoration materials: a review of the literature. Saudi J Dent Res 2015;6:33-40

3 Dagar S, Pakhan A, Tunkiwala A. An invitro evaluation of flexural strength of direct and indirect provisionalization materials. J Indian Prosthodont Soc 2005;5(3):132-135

4 Federick DR. The provisional fixed partial denture. J Prosthet Dent 1975;34(5):520-526

5 Strassler HE. In-office provisional restorative materials for fixed prosthodontics. Inside Dentistry 2009;5(4):1-7

6 Ehrenberg D, Weiner GI, Weiner S. Long-term effects of storage and thermal cycling on the marginal adaptation of provisional resin crowns: a pilot study. J Prosthet Dent 2006;95(3): 230-236
7 Monday JJ, Blais D. Marginal adaptation of provisional acrylic resin crowns. J Prosthet Dent 1985;54(2):194-197

8 Nivedita S, Prithviraj DR. A comparative study to evaluate the marginal accuracy of provisional restorations fabricated by light polymerized resin and auto polymerized resin: a scanning electron microscope study. J Indian Prosthodont Soc 2006;6(3):122-127

9 Diaz-Arnold AM, Dunne JT, Jones AH. Microhardness of provisional fixed prosthodontic materials. J Prosthet Dent 1999;82(5):525-528

10 Savabi O, Nejatidanesh F, Fathi MH, Navabi AA, Savabi G. Evaluation of hardness and wear resistance of interim restorative materials. Dent Res J (Isfahan) 2013;10(2):184-189

11 Ogawa T, Aizawa S, Tanaka M, Matsuya S, Hasegawa A, Koyano K. Effect of water temperature on the fit of provisional crown margins during polymerization. J Prosthet Dent 1999;82(6):658-661

12 Dhillon N, Kumar M, D'Souza D. Effect of water temperature and duration of immersion on the marginal accuracy of provisional crowns. Med J Armed Forces India 2011;67(3):237-240

13 Adnan S, Khan FR, Umer F. An in vitro comparison of marginal accuracy in temporary crowns. J Contemp Dent 2013;3(3):121-126

14 Verma R, Nagpal A, Verma PR, Chadda AS. Marginal accuracy of provisional restorative materials used in fixed partial dentures an in-vitro study. Indian J Dent Sci 2012;3(4):25-29

15 Young HM, Smith CT, Morton D. Comparative in vitro evaluation of two provisional restorative materials. J Prosthet Dent 2001;85(2):129-132

16 Kim SH, Watts DC. Polymerization shrinkage-strain kinetics of temporary crown and bridge materials. Dent Mater 2004;20(1):88-95 